‡USGS

science for a changing world

Prepared in cooperation with the

ARKANSAS SOIL AND WATER CONSERVATION COMMISSION

\title{
ALTITUDE OF THE TOP OF THE SPARTA SAND AND MEMPHIS SAND IN THREE AREAS OF ARKANSAS
}

Water-Resources Investigations Report 98-4002

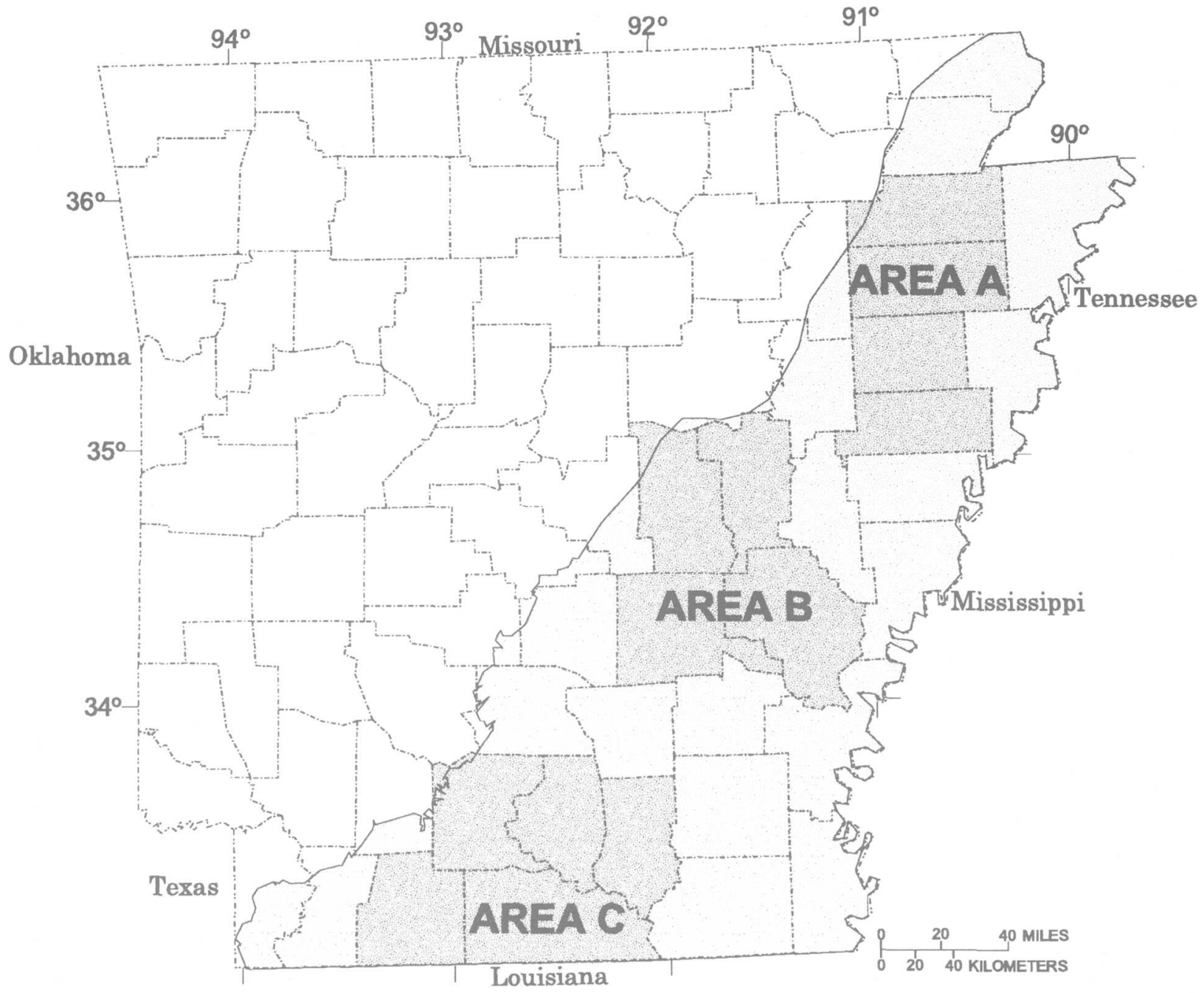

U.S. Department of the Interior

U.S. Geological Survey 


\section{ALTITUDE OF THE TOP OF THE SPARTA SAND AND MEMPHIS SAND IN THREE AREAS OF ARKANSAS}

By Aaron L. Pugh, Paul W. Westerfield, Gerard J. Gonthier, and David T. Poynter

U.S. GEOLOGICAL SURVEY

Water-Resources Investigations Report 98-4002

Prepared in cooperation with the ARKANSAS SOIL AND WATER CONSERVATION COMMISSION 


\section{U.S. DEPARTMENT OF THE INTERIOR}

BRUCE BABBIT, Secretary

\section{U.S. GEOLOGICAL SURVEY}

Thomas J. Casadevall, Acting Director

For additional information write to:

District Chief

U.S. Geological Survey, WRD

401 Hardin Road

Little Rock, Arkansas 72211
Copies of this report can be purchased from:

U.S. Geological Survey

Branch of Information Services

Box 25286

Denver Federal Center

Denver, Colorado 80225 


\section{CONTENTS}

Abstract.
Introduction
Description of Sparta Sand and Memphis Sand
Data Analysis and Map Construction
Top of Sparta Sand and Memphis Sand
Summary.

\section{PLATES}

Plate 1. Map showing altitude of the top of the Sparta Sand and Memphis Sand, Area A .................................... In pocket

2. Map showing altitude of the top of the Sparta Sand and Memphis Sand, Area B

In pocket

3. Map showing altitude of the top of the Sparta Sand and Memphis Sand, Area C

In pocket

\section{ILLUSTRATIONS}

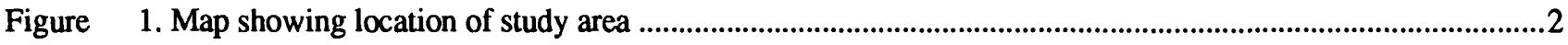

2. Diagrammatic map showing major structural features affecting the Sparta Sand and

Memphis Sand in Arkansas 
m 


\title{
ALTITUDE OF THE TOP OF THE SPARTA SAND AND MEMPHIS SAND IN THREE AREAS OF ARKANSAS
}

\author{
by Aaron L. Pugh, Paul W. Westerfield, Gerard J. Gonthier, and David T. Poynter
}

\begin{abstract}
The Sparta Sand and Memphis Sand form the second most productive aquifer in Arkansas. The Sparta Sand and Memphis Sand range in thickness from 0 to 900 feet, consisting of fine- to mediumgrained sands interbedded with layers of silt, clay, shale, and minor amounts of lignite. Within the three areas of interest, the top surface of the Sparta Sand and Memphis Sand dips regionally east and southeast towards the axis of the Mississippi Embayment syncline and Desha Basin. Local variations in the top surface may be attributed to a combination of continued development of structural features, differential compaction, localized faulting, and erosion of the surface prior to subsequent inundation and deposition of younger sediments.
\end{abstract}

\section{INTRODUCTION}

The Sparta Sand and Memphis Sand form the Sparta and Memphis aquifers in eastern and south-central Arkansas. The term "Sparta-Memphis aquifer" has been used previously to describe a single aquifer but the formal name is "Sparta and Memphis aquifers," which together form a single aquifer system. The Sparta and Memphis aquifers are the second most productive aquifer system in Arkansas (Holland, 1987). Historically, the system has experienced major withdrawals for industrial and public supply, and over the last decade has experienced increasing withdrawals for agricultural uses (Holland, 1987; 1993). Water-level data from the Sparta and Memphis aquifers indicate steadily declining water levels where relatively large withdrawals occur (Stanton, 1997).

In 1990, approximately 222 million gallons per day (Mgal/d) of water were withdrawn from the Sparta and Memphis aquifers system, of which more than 86 percent was withdrawn from three areas (Holland, 1993) (fig. 1). Little or no well log data exist outside these three areas. A northern area (Area A), Craighead, Cross, Poinsett, and St. Francis Counties, averaged approximately $1 \mathrm{Mgal} / \mathrm{d}$ of water withdrawals; a central area (Area B), Arkansas, Jefferson, Lonoke, and Prairie Counties, averaged approximately $172 \mathrm{Mgal} / \mathrm{d}$ of water withdrawals; and a southern area (Area C), Bradley, Calhoun, Columbia, Ouachita, and Union Counties, averaged approximately $18 \mathrm{Mgal} / \mathrm{d}$ of water withdrawals (fig. 1).

The U.S. Geological Survey, in cooperation with the Arkansas Soil and Water Conservation Commission, conducted a study to prepare maps showing the altitude of the top of the Sparta Sand and Memphis Sand in the areas described above. These maps, presented in this report, will be useful geohydrologic tools for scientists, engineers, and water managers examining the Sparta and Memphis aquifers system. Earlier publications (Cushing and others, 1964; Hosman and others, 1968; Payne, 1968; 1972; 1975; Petersen and others, 1985) include similar maps but were regional in scope, and, therefore, less detailed or did not include all of the areas of interest (Areas A, B, and C) for this study. Some of the data used in this study are available as a result of a continuing cooperative program with the Arkansas Geological Commission.

\section{DESCRIPTION OF SPARTA SAND AND MEMPHIS SAND}

The Sparta Sand and Memphis Sand are part of the Claiborne Group in the Eocene Series, stratigraphically. Within Arkansas, these units together cover approximately the southeastern one-third of the State (fig. 1) and range in thickness from 0 to 900 feet. Both units were deposited as a delta-fluvial plain complex and consist of fine- to medium-grained sands inter- 


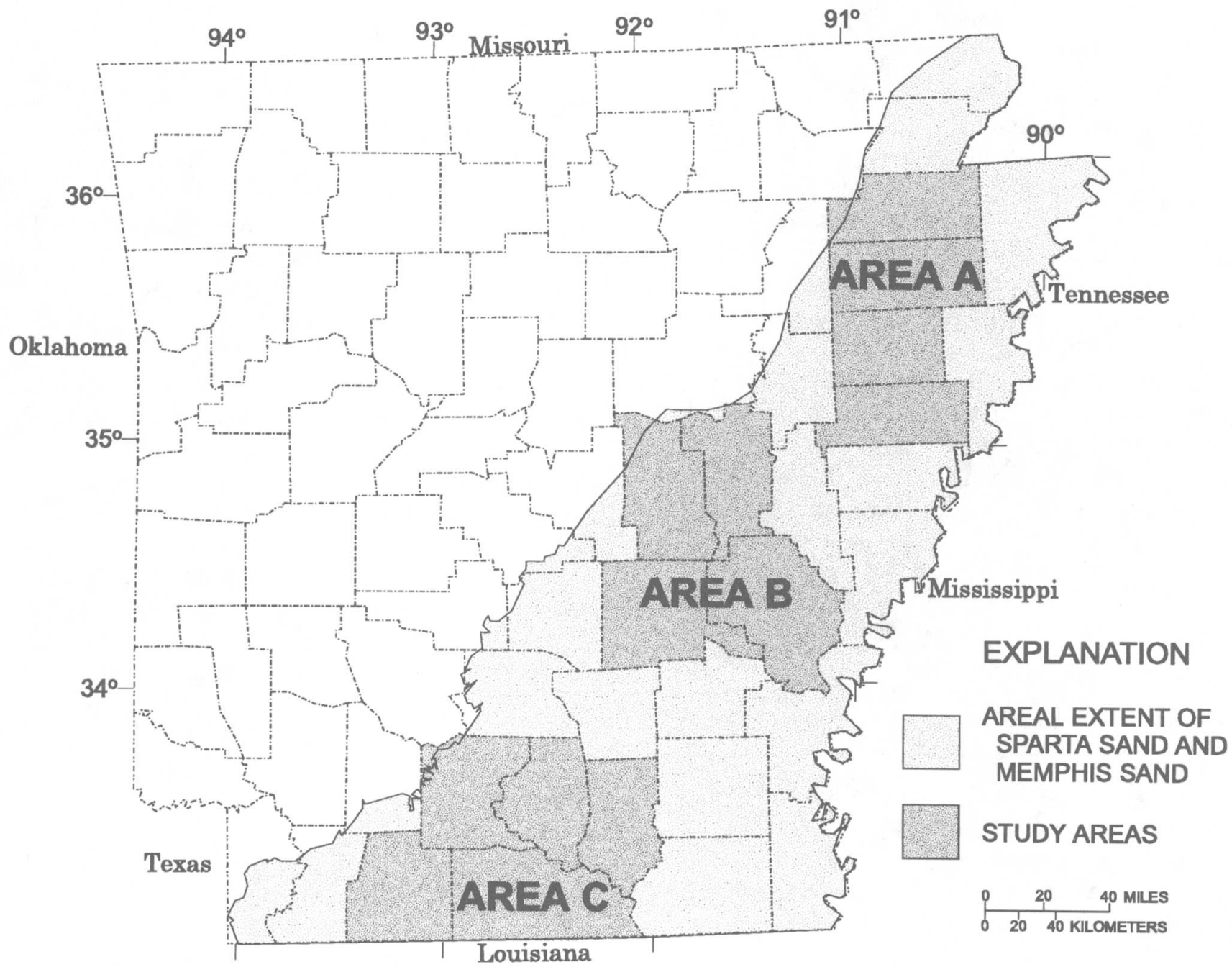

Figure 1. Location of study area. 
bedded with layers of silt, clay, shale, and minor amounts of lignite. In the east-central and southern portions of Arkansas (Areas B and C), the Sparta Sand is underlain by the Cane River Formation that serves as a lower confining unit for the Sparta aquifer and consists of 200 to $800 \mathrm{ft}$ of low-permeability marine clay. In the east-central portion of Arkansas (Areas A and B), near latitude $35^{\circ}$ north, the Cane River Formation changes lithologically from clay to sand, forming a single sand unit from the bottom of the Carrizo Sand, which underlies the Cane River Formation, to the top of the Sparta Sand (Hosman and others, 1968). North of this facies change, the Claiborne Group is not subdivided into the Sparta Sand, Cane River Formation, and Carrizo Sand, but the equivalent section is a single formation called the Memphis Sand. The Memphis Sand is underlain by a thick layer of clay that is part of the upper Wilcox Group and is the lower confining unit for the Memphis aquifer in this area. The Sparta and Memphis aquifers system is overlain by the Cook Mountain Formation that serves as the upper confining unit and typically consists of 100 to $150 \mathrm{ft}$ of carbonaceous clays.

\section{DATA ANALYSIS AND MAP CONSTRUCTION}

The structural tops of the Sparta Sand and Memphis Sand were identified by analyzing driller's and geophysical logs from nearly 400 wells that penetrated the top of those units in eastern and south-central

Arkansas. The driller's and geophysical logs were provided by the Arkansas Geological Commission and the Arkansas Water Well Construction Committee and may be found on file at their offices in Little Rock, Arkansas. Each log contains information on well location, land surface altitude, depths to lithologic contacts, and the total depth of the well. Well logs were analyzed to determine the depth of the contact between the Cook Mountain Formation and the Sparta Sand or Memphis Sand. Well log data were compiled into a digital data base and the altitude of the top of the units was determined by subtracting the depth to the contact with the top of the unit from the land surface altitude at the well head. These data were then contoured and the resulting computer-generated maps were modified to eliminate erroneous well log data and to improve interpretation. Little or no data exist outside the Area boundaries. Some dashed contours are extrapolations of the data.

\section{TOP OF SPARTA SAND AND MEMPHIS SAND}

The structural top of the Sparta Sand and Memphis Sand is shown by contour maps for the three areas of interest (plates 1,2, and 3). For the three areas examined, three major structural features influenced the thickness and top surface of the Sparta Sand and Memphis Sand (fig. 2). The Mississippi Embayment, a relatively symmetrical syncline with a south-southwest axial trend in the northeastem portion of Arkansas, broadens into the triangular-shaped Desha Basin in southeastern Arkansas and adjacent portions of Mississippi, forming a south-southwest-oriented spoonshaped basin and syncline north of the Monroe uplift in southern Arkansas and northern Louisiana and adjacent portions of Mississippi. The Mississippi Embayment and Desha Basin were developing during the same time period as the deposition of the sediments of the Sparta Sand and Memphis Sand. Both structural features, particularly the Mississippi Embayment, continued to downwarp after the deposition of the Sparta Sand and Memphis Sand was completed (Payne, 1968). The effect of this downwarping was the steepening of the upper surface dip on the basinward flanks towards the axis. Downwarping into the Desha Basin may be seen in the southern portion of Area B (plate 2).

Along the eastern edge of Arkansas, the top surface of the Sparta Sand and Memphis Sand dips regionally to the south, southwest, and west at 25 to 50 feet per mile toward the axis of the Mississippi Embayment syncline. For the remainder of Arkansas, where the Sparta Sand or Memphis Sand is present, the top surface of the units dips regionally east and southeast at about the same rate, again towards the axis of the Mississippi Embayment syncline. Evidence of the regional dip to the east and southeast is indicated by the contours in Areas A, B, and C (plates 1, 2, and 3).

Local variations in the top surface of the Sparta Sand and Memphis Sand are common and in some areas pronounced. These local variations may be associated with variations in the extent and amount of structural downwarping of the Mississippi Embayment and Desha Basin. Some variations may be associated with differential compaction of the shales, clays, and sands that constitute the Sparta Sand and Memphis Sand. Some variations may be associated with erosion of the surface by channels cutting across the units before the area was again inundated by the sea and deposition of younger sediments resumed. Variations also may be associated with local faulting of the units following 


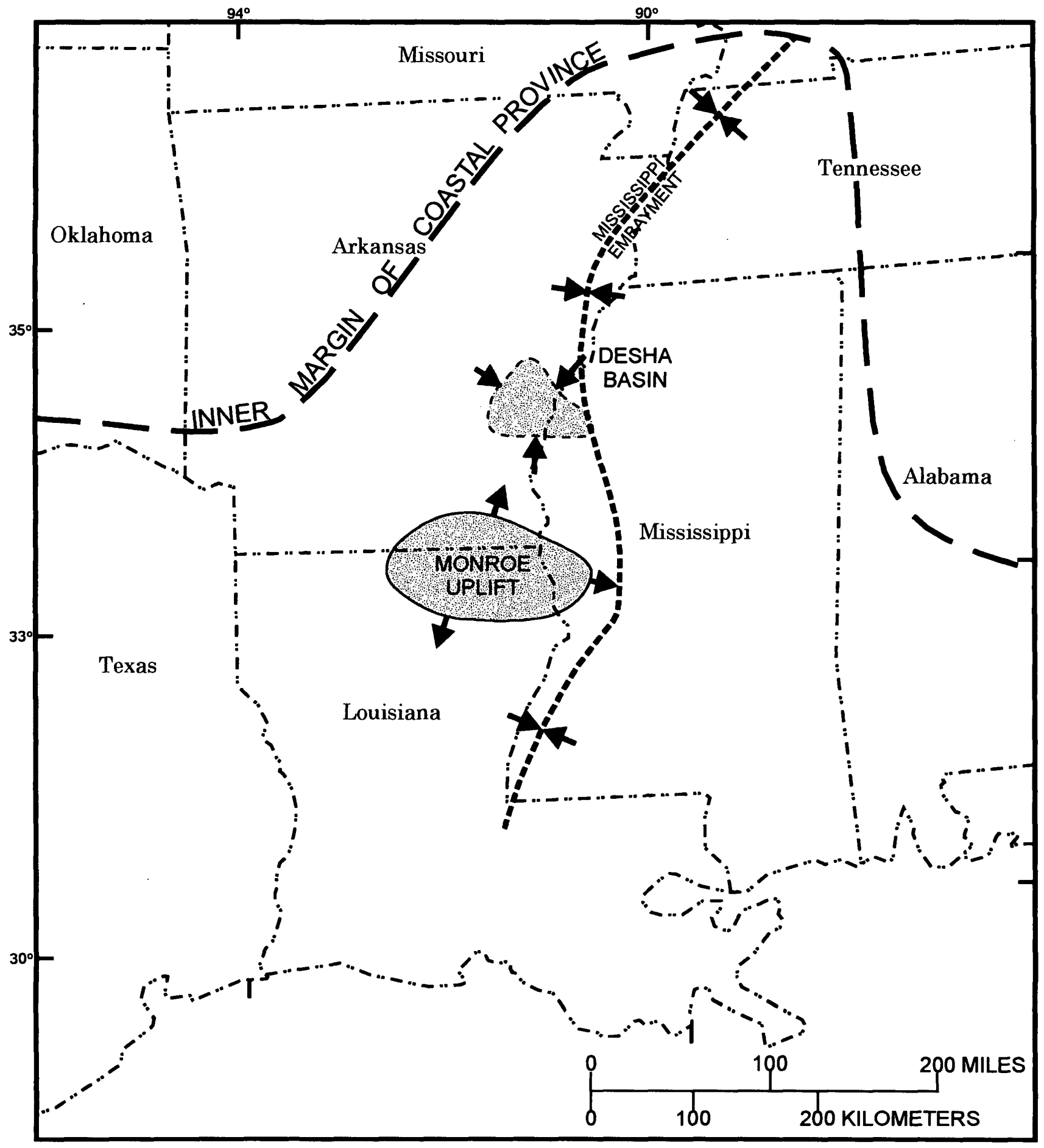

Figure 2. Major structural features affecting the Sparta Sand and Memphis Sand in Arkansas (modified from Murray, 1961). 
deposition as illustrated in Area C (plate 3). The variations in the top surface of the Sparta Sand and Memphis Sand were probably caused by combinations of all four processes: continued structural development, differential compaction, surface erosion, and localized faulting.

\section{SUMMARY}

The Sparta Sand and Memphis Sand form the second most productive aquifer in Arkansas. The Sparta Sand and Memphis Sand range in thickness from 0 to 900 feet, consisting of fine- to mediumgrained sands interbedded with layers of silt, clay, shale, and minor amounts of lignite. Within the three areas of interest, data from nearly 400 wells indicate that the top surface of the Sparta Sand and Memphis Sand dips regionally east and southeast towards the axis of the Mississippi Embayment syncline and Desha Basin. Along the eastern edge of Arkansas, the top surface of the Sparta Sand and Memphis Sand dips regionally to the south, southwest, and west. In all of these areas, the Sparta Sand and Memphis Sand dip at a rate of about 25 to 50 feet per mile. Local variations in the top surface may be attributed to a combination of continued development of structural features, differential compaction, localized faulting, and erosion of the surface prior to subsequent inundation and deposition of younger sediments.

\section{SELECTED REFERENCES}

Broom, M.E., Kraemer, T.F., and Bush, W.V., 1984, A reconnaissance study of saltwater contamination in the El Dorado aquifer, Union County, Arkansas: U.S. Geological Survey Water-Resources Investigations Report 84$4012,47 \mathrm{p}$.

Cushing, E.M., Boswell, E.H., and Hosman, R.L., 1964, General geology of the Mississippi Embayment: U.S. Geological Survey Professional Paper 448-B, 28 p.

Edds, Joe, and Fitzpatrick, D.J., 1989, Altitude of the potentiometric surface and changes in water levels in the Sparta-Memphis aquifer in eastern and southern Arkansas, spring 1986: U.S. Geological Survey WaterResources Investigations Report 88-4042, 1 sheet.

Fitzpatrick, D.J., Kilpatrick, J.M., and McWreath, H.C., 1990, Geohydrologic characteristics and simulated response to pumping stresses in the Sparta aquifer in east-central Arkansas: U.S. Geological Survey WaterResources Investigations Report 88-4201, 50 p.

Halberg, H.N., 1972, Use of water in Arkansas, 1970: Arkansas Geological Commission Water Resources Summary Number 7,17 p.
1977, Use of water in Arkansas, 1975, Arkansas Geological Commission Water Resources Summary Number 9, $28 \mathrm{p}$.

Halberg, H.N., and Stephens, J.W., 1966, Use of water in Arkansas, 1965: Arkansas Geological Commission Water Resources Summary Number 5, $12 \mathrm{p}$.

Holland, T.W., 1987, Use of water in Arkansas, 1985: Arkansas Geological Commission Water Resources Summary Number 16, $27 \mathrm{p}$.

1993, Use of water in Arkansas, 1990: U.S. Geological Survey Open-File Report 93-48, pamphlet.

Holland, T.W., and Ludwig, A.H., 1981, Use of water in Arkansas, 1980: Arkansas Geological Commission Water Resources Summary Number 14, $30 \mathrm{p}$.

Hosman, R.L., 1969, Geohydrology of the Coastal Plain aquifers of Arkansas: U.S. Geological Survey Hydrologic Investigations Atlas 309, 1 sheet.

1982, Outcropping Tertiary units in southern Arkansas: U.S. Geological Survey Miscellaneous Investigations Series I-1405, 1 sheet.

Hosman, R.L., Long, A.T., Lambert, T.W., and others, 1968, Tertiary aquifers in the Mississippi Embayment: U.S. Geological Survey Professional Paper 448-D, 29 p.

Kilpatrick, J.M., 1992, Simulated response to future pumping in the Sparta aquifer, Union County, Arkansas: U.S. Geological Survey Water-Resources Investigations Report 91-4161, 25 p.

Murray, G.E., 1961, Geology of the Atlantic and Gulf Coastal Province of North America: New York, Harper \& Brothers, $692 \mathrm{p}$.

Payne, J.N., 1968, Hydrologic significance of the lithofacies of the Sparta Sand in Arkansas, Louisiana, Mississippi, and Texas: U.S. Geological Survey Professional Paper 569-A, $17 \mathrm{p}$.

1972, Hydrologic significance of lithofacies of the Cane River Formation of equivalents of Arkansas, Louisiana, Mississippi and Texas: U.S. Geological Survey Professional Paper 569-C, 17 p.

1975, Geohydrologic significance of lithofacies of the Carrizo Sand of Arkansas, Louisiana, and Texas and the Meridian Sand of Mississippi: U.S. Geological Survey Professional Paper 569-D, $11 \mathrm{p}$.

Petersen, J.C., Broom, M.E., and Bush, W.V., 1985, Geohydrologic units of the Gulf Coastal Plain in Arkansas: U.S. Geological Survey Water-Resources Investigations Report 85-4115, $20 \mathrm{p}$.

Stanton, G.P., 1997, Potentiometric surface and specific conductance of the Sparta and Memphis aquifers in eastern and south-central Arkansas, 1995: U.S. Geological Survey Water-Resources Investigations Report 97-4119, $16 \mathrm{p}$.

Terry, J.E., Bryant, C.T., Ludwig, A.H., and Reed, J.E., 1979, Water-resources appraisal of the south-Arkansas lignite area: U.S. Geological Survey Open-File Report 79-924, $162 \mathrm{p}$. 
$\triangle$ ०

응 골

음. ․ㅗ․

$\stackrel{0}{\circ}$

क范

당

ญ

$\sum_{D}$

\%

호음

윽

곡

엄

유

검

O

D

S

z

z

畗

攵

고

而

妿

总

유 